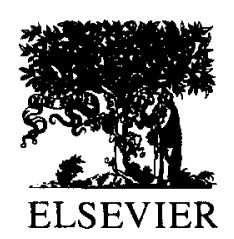

Japan and the World Economy 8 (1996) 309-333

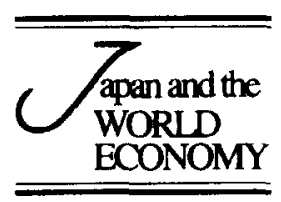

\title{
Japan's persistent trade surplus: Policies for adjustment $^{1}$
}

\author{
F. Gerard Adams ${ }^{\mathrm{a}}$, Byron Gangnes ${ }^{\mathrm{b}, *}$ \\ ${ }^{2}$ University of Pennsylvania, Philadelphia, Pennsylvania, USA \\ ${ }^{b}$ Department of Economics, University of Hawaii at Manoa, 2424 Maile Way, Room 542. \\ Honolulu, HI 96822, USA
}

Accepted 15 July 1995

\begin{abstract}
While part of the recent increase in the Japanese trade surplus can be attributed to the Japanese recession, the surplus has widened despite the appreciation of the yen and enactment of policies to open Japanese markets. We review the trade surplus issue in the light of theories of trade and current account adjustment. We evaluate the potential for exchange appreciation and Japanese fiscal policy to reduce the imbalance, estimating their effects using simulations of the NIRA-LINK model of the US - Japan-world economy. The simulations show that moderate use of macropolicies would not be sufficient to eliminate the trade imbalance.
\end{abstract}

Keywords: Japanese trade surplus; Econometric simulations

JEL classification: $\mathrm{F} 32 ; \mathrm{F} 47 ; \mathrm{C} 53$

\footnotetext{
*Corresponding author. Tel.: 808-956-7285; fax: 808-956-4347; e-mail: gangnes $a$ hawaii.edu.

${ }^{1}$ This project is part of the collaboration between the International Centre for the Study of East Asian Development (ICSEAD), Kitakyushu, Japan and the University of Pennsylvania. An earlier version of this paper was presented at the World Project LINK Meeting, Beijing, China, September 1993 .
} 


\section{Introduction}

After falling in the late 1980s, the Japanese trade surplus has been on the rise recently. Since 1990, the merchandise trade surplus has soared from just over $\$ 60$ billion to more than $\$ 145$ billion. Mirroring this has been new deterioration in the trade and current account positions of the United States, the EC, and increasingly the Asian developing countries. While the recent surge is partly attributable to the sharp slowdown in Japan, the long-run persistence of the surplus has economists and policymakers scratching their heads. Why has adjustment been so slow? Will the belated yen appreciation finally make a difference? Can the surplus be eliminated through macroeconomic policies alone, or will managed trade policies or other structural change be required?

In this paper, we discuss the development of the Japanese trade surplus and evaluate macroeconomic policies that might be used to address it. After briefly describing the extent of the surplus problem, we review theoretical approaches to trade and current account adjustment and discuss their implications for Japanese surplus reduction. We then describe an empirical model that we use to evaluate alternative adjustment policies. Simulations of yen appreciation and an accommodating Japanese fiscal stimulus suggest that macro policies are not a particularly powerful tool for resolving the imbalance problem.

\section{The intractable Japanese surplus}

The Japanese trade surplus has been a festering political problem for the past decade. After maintaining approximate trade balance during the period of rapid post-war development, Japan's surplus began to grow during the 1970s. The trade imbalance became a major concern in the US during the early 1980s, when America went from a position of modest current account surpluses to significant deficits, as a result of the marked appreciation of the dollar after 1978 and sharp fiscal expansion under the Reagan Administration. The Japanese trade surplus reached almost $\$ 100$ billion dollars by 1986 (see Fig. 1), the bilateral deficit with the US contributing roughly a half.

The Japanese surplus "problem" receded from view in the late 1980s. The dollar collapse of 1985-1986, together with an investment boom in Japan, helped to reduce the surplus considerably. After J-curve delays, the Japanese trade surplus fell to just over $\$ 60$ billion dollars by 1990 . The US share of the remaining deficit was also smaller. It appeared that the surplus problem had been licked.

Beginning with the end of the bubble economy, and the subsequent economic recovery in the US, the Japanese trade surplus began to grow once more. In two years, it doubled in size, measured in dollars. Predictably, politicians in 


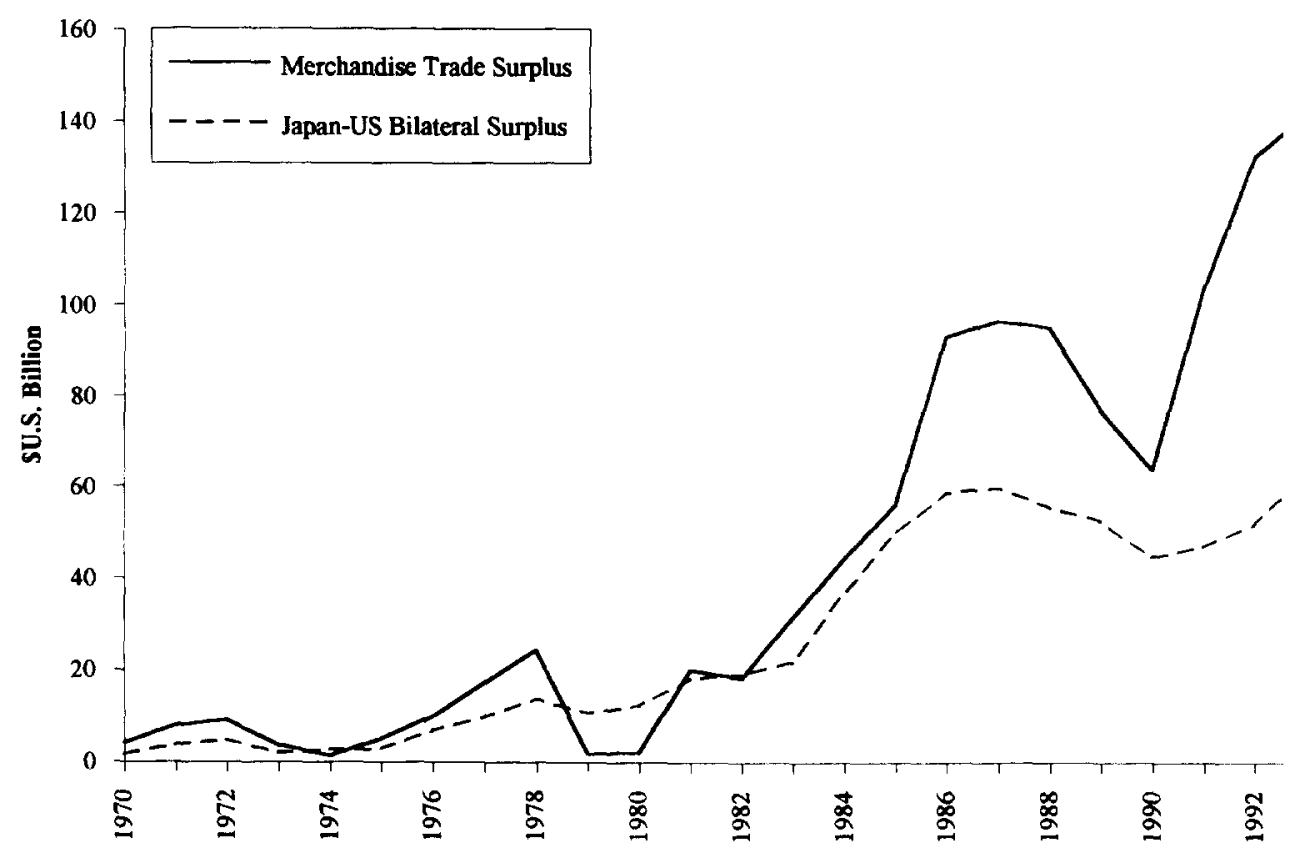

Fig. 1. Japan's merchandise trade surplus.

the West were soon decrying the surplus and the uncompetitive Japanese practices that allegedly underlay it. Despite the surge, the yen remained fairly weak against the dollar, and there was little sign of an imminent recovery in Japan. Finally, in 1993, 1994 and early 1995, the yen began to appreciate sharply, lending hope that the trade surge might at last be reversed. Whether that will indeed be the case depends on the permanence of the currency movements, their impact on the equilibrium determinants of trade flows, and the extent to which other government policies are altered to facilitate adjustment.

While the Japanese surplus shows no immediate signs of abating, the problem is certainly not as bad as recent numbers suggest. The surplus since 1991 has been driven upward by the severe and extended Japanese economic downturn. Once growth and imports revive, the surplus is likely to fall back somewhat. (For calendar year 1994, the merchandise trade balance fell $7.3 \%$ measured in yen, although it still rose 3\% in dollar terms, to $\$ 146$ billion.) Our concern is with the trade surplus that will almost certainly remain, why such a large surplus has persisted, and the potential for yen appreciation and other macroeconomic policies to address the imbalance. 


\section{Trade and current account adjustment in theoretical models}

The persistence of the Japanese trade and current account surplus amply illustrates that balance of payments imbalances can be sustained for prolonged periods. In this case at least there do not appear to be any dramatic mechanisms that eliminate imbalances in the short run. But economists have long argued that continued current account surpluses cannot be consistent with a sustainable long-run equilibrium for the world economy. What adjustment mechanisms operate to close current account gaps in the long run?

Traditional trade-based approaches to balance of payments adjustment (Robinson, 1937; Machlup, 1939) stress the role of flexible international relative prices in trade adjustment. A trade imbalance reflects excess demand for the goods of one country and excess supply of the goods of the partner country. Relative prices will change to eliminate these excess demands. The success and speed of adjustment to long-run balanced trade depends principally on trade elasticities, summarized in the familiar Marshall-Lerner condition, as well as spending propensities of home and foreign residents.

An explicit automatic adjustment mechanism is introduced in such models by imposing a gold standard specie-flow rule that links current account surpluses to accumulation of money balances from abroad. Accumulated gold increases the domestic money supply, raising the price level and improving the terms of trade. The increasing relative price of domestic goods then reduces their excess demand and begins to close the current account surplus. Monetary approach authors (e.g. Frenkel and Johnson, 1976; Dornbusch, 1973) described a similar adjustment mechanism, but with money accumulation directly affecting expenditure levels, rather than relative prices.

For a system of floating exchange rates, as has prevailed among major currencies since the early 1970 s, relative price adjustment may be achieved primarily through changes in the exchange rate, rather than national price levels. But the basic adjustment question is the same: how much relative price adjustment will occur, and to what extent will this have the desired balance of payments impact.

Writers of the "absorption approach" school (Alexander, 1952; Tsiang, 1961) generalized the elasticity model to incorporate direct and induced effects of relative price change on income and absorption. The multiplier reduction in activity accompanying a terms of trade improvement, for example, tends to limit surplus reduction by restraining imports. On the other hand, the deflation associated with revaluation may raise real money balances and stimulate absorption, reinforcing current account adjustment. The literature identifies a large number of such effects, with no unambiguous net result for trade balance adjustment (see Pilbeam, 1992, pp. 65-71).

Price elasticities remain key behavioral parameters governing adjustment in the elasticity-absorption models. A deterioration in the terms of trade (from 
an exchange devaluation or price level change) will improve the trade balance if the Marshall-Lerner condition holds, that is, if the sum of domestic and foreign import price elasticities exceeds one. ${ }^{2}$ Empirical studies have consistently supported the Marshall-Lerner condition for industrialized economies, including the US and Japan, although sometimes only after a considerable lag. ${ }^{3}$ The adverse "J-curve" movements of trade balances following a terms of trade deterioration may last up to two years before the trade balance begins to improve (Artus and Knight, 1984).

The inertia apparent in the US current account response to the 1986 dollar depreciation prompted a re-evaluation of traditional views about relative price and trade balance adjustment. Krugman (1987), Dornbusch (1987) and others hypothesized that price adjustment following a depreciation may be limited if exporting firms enjoy market power in destination countries. They may limit the "pass through" of exchange rates into export prices to protect market share. Dixit (1989) and Baldwin (1988) were among researchers who suggested that dollar depreciation might not reverse market share gains made by Japanese firms in the early 1980s. Having incurred substantial fixed costs in entering the US market, firms would be reluctant to leave unless very substantial depreciation occurred, so that the current account deficit might have experienced a permanent (hysteretic) increase during the dollar cycle. However, by the end of the decade, empirical evidence suggested to some economists (Krugman, 1991) that price and current account responses may not have been so unusual after all, and that the traditional J-curve story seemed to hold fairly well in retrospect.

In the elasticity-absorption approach to adjustment, there is little if any recognition that current account imbalances imply changing patterns of international asset-holding. The modern portfolio-balance approach (Kouri, 1976; Obstfeld, 1981) explicitly recognizes this link, and delineates its effect on exchange rates. A surplus country acquires net foreign assets. This both directly raises its wealth and disturbs its portfolio of assets. As investors reshuffle asset portfolios, their demands for currencies lead to exchange rate changes that, along with wealth changes, begin to close the current account surplus.

While responsiveness to relative price changes may still play a role in assetmarket adjustment models, an entirely new set of factors is in the foreground: the preferences of investors over alternative assets and the response of exchange rates to their actions. Current account adjustment may be swift if investors in surplus countries resist accumulating foreign assets and drive

\footnotetext{
${ }^{2}$ The Marshall-Lerner condition is sufficient for trade balance improvement only if export and import supply elasticities are infinite and if the initial trade balance is zero. For the more general case, see Robinson (1937).

${ }^{3}$ See Goldstein and Khan (1985), and for a recent survey, Hooper and Marquez (1993). However, Rose (1991) presents an econometric critique of this result.
} 
foreign exchange rates down sharply. It may be quite slow if they are content to recycle foreign currency abroad. The changing willingness of Japanese investors to acquire dollar assets has been an important factor in the magnitude and timing of recent yen appreciations. The importance of central bank action is also transparent; central bank sterilization can prevent or delay adjustment by eliminating excess demands for currencies.

The growth in the US current account deficit in the mid-1980s mirrored a surge in US investment relative to savings and sharply rising US government budget deficits. These events revived interest in the analysis of current account imbalances as the counterpart to savings-investment imbalances, a view that had earlier been emphasized by the absorption approach school. A number of economists (see especially Frenkel and Razin, 1992; Razin, 1993) constructed modern optimizing models of the world economy that illustrate the importance of consumer preferences toward consumption and savings and government fiscal policies for global trade patterns and international transmission. These models provide fundamental behavioral explanations for current account patterns and indicate how changes in consumer behavior and government policies might contribute to reduction in imbalances.

\section{Why has the Japanese surplus persisted?}

The above review identifies mechanisms by which trade imbalances can be eliminated and factors affecting such adjustment. We can draw on this discussion to address the first of our central questions: why has Japanese trade adjustment been so slow?

Traditional models of trade and current account adjustment suggest that terms of trade improvement should play a central role in reducing the Japanese surplus. The effectiveness of yen appreciation in closing the current account gap will depend on the extent of real exchange rate change and the behavioral response of Japanese consumers and firms, traditionally measured by import price elasticities. In nominal terms the yen's appreciation after 1985 was substantial, rising from 260 yen per dollar to 125 yen per dollar by 1988 . But real yen appreciation was much less pronounced. On a relative export price basis, the yen was dramatically undervalued prior to 1985 , and remained significantly so even after its 1986 slide. $^{4}$ (NLI Research, 1993.) In addition, some of the yen's gains were reversed temporarily during 1989-1990. The relative deflation of Japanese prices may have resulted in part from differing domestic and foreign inflation conditions, and perhaps also pricing-to-market

\footnotetext{
${ }^{4}$ Hooper and Marquez (1993) note that the trade-weighted average relative export price actually declined $10 \%$ over the $1980-1992$ period.
} 
behavior by Japanese exporters. Regardless of the cause, the effect was to yield terms-of-trade changes much smaller than is commonly believed.

That there was little additional yen appreciation after 1985-1986 is surprising considering the mounting Japanese surplus. The asset market view of foreign exchange argues that Japanese investors will resist accumulating foreign assets without an increase in foreign rates of return, putting upward pressure on the yen. This portfolio adjustment process appears to have been impeded in the 1980s by unusually strong Japanese appetite for foreign (US) assets. Until 1991-1992, the Japanese surplus was almost entirely recycled as direct foreign investments and purchases of other long-term foreign asset. Since then, the Japanese financial crisis, recession, and lower US dollar returns dramatically reduced Japanese interest in acquiring dollar assets and has shifted Japanese capital flows toward short-term outflows and foreign debt retirement. As portfolio balance models would suggest, with the redirection of asset demands away from dollar assets, the upward movement of the yen has resumed.

What real appreciation that has occurred may have had limited effects on the trade surplus because of the relatively weak price responsiveness of Japanese trade flows. While estimates vary considerably, price elasticities of Japanese imports are frequently found to be smaller than for the US and other developed market economies. ${ }^{5}$ This will limit the import surge associated with a given yen appreciation. Business cycle developments have worked against relative price effects. As noted above, fluctuations in economic activity have contributed to recent evolution of the Japanese surplus. Imports surged and the trade balance receded with the strong pickup in demand in the late 1980s. Since 1990, weak Japanese demand has dampened absorption relative to income and permitted the trade imbalance to widen. In the empirical section, below, we explore both the sensitivity of the imbalance to relative price changes and the adjustment potential of a government stimulus to demand.

To some economists the chief impediment to Japanese trade adjustment remains the net savings shortfall in Western countries and surplus in Japan. On the surface this observation is a tautology: current account imbalances necessarily represent savings-investment imbalances, without this telling us much about how savings and investment are determined. But proponents of this view generally have two culprits in mind: the chronic US government budget deficit that consumes US private savings, and the markedly lower private savings rate in the US compared with Japan. Their number one

\footnotetext{
${ }^{5}$ Hooper and Marquez (1993) report an average Japanese import price elasticity of -0.7 for five recent studies of Japanese trade, compared with average US elasticity of -0.9 in ten recent studies. For exports, they report an average Japanese elasticity of $-\mathbf{0 . 8}$, compared with an average for 8 US studies of -0.9 . Their own estimates are very close to these averages. They note that there is considerable variation across studies in trade elasticity estimates.
} 
prescription is usually a reduction in US deficit spending. ${ }^{6}$ On the flip side, any development that encourages a reduction in Japanese net savings rates will also reduce the savings-investment gap, including gradual behavioral shifts toward consumption among the Japanese populace, or policies to stimulate consumption such as measures to open Japanese import markets. Such structural change in Japan has been aided by recent fiscal changes that have eliminated the Japanese public sector surplus.

\section{Prospects for surplus reduction: A simulation analysis}

Recent progress in eliminating macroeconomic imbalances may produce further surplus reduction. The Japanese portfolio reshuffling and 1993-1995 yen appreciation may mean some trade adjustment is already "in the pipeline". Early success reducing the US structural budget deficit and recent Japanese fiscal stimulus measures may also help by reducing savings-investment imbalances. How far will macroeconomic adjustments take us? Can macroeconomic policies alone close the trade gap, or will we need to see more far-reaching structural change in the Japanese economy and its trade relationships? In this section we present a simulation model approach to answering these questions, focusing on two potential sources of adjustment: the recent sharp yen appreciation, and the possibility of additional fiscal stimulus in Japan.

\subsection{The NIRA model of the US-Japan-world economy}

Econometric model analysis can contribute to the Japanese surplus debate by providing quantitative estimates of the impacts of alternative adjustment measures. Model simulations can gauge both the contributions of macroeconomic policy to surplus reduction and macro and industry-level consequences. Here we report results of a simulation study of Japanese surplus adjustment conducted using the large-scale NIRA model of the US-Japanworld economy.

The NIRA US-Japan-LINK model combines industrially detailed econometric models of the US and Japan within the global framework of Project LINK to provide a tool for consistent evaluation of macro and sectoral policies (Adams et al., 1993a). ${ }^{7}$ The US and Japanese models are com-

\footnotetext{
${ }^{6}$ Ronald McKinnon has been among the most vocal proponents of this view. For an overview of his debate with "traditional" trade economists (played here by William Cline) see The Economist (1993).

${ }^{7}$ For a description of the Project LINK model, see Bodkin et al. (1991).
} 
plete macroforecasting models of the two economies, linked through trade at the industry level, making the system an appropriate tool for evaluating both macro and industry-based measures to address the Japanese surplus problem. Although the primary focus of this exercise is on movements in the overall trade balance, the model also provides information on how the burdens of adjustment would be distributed across various sectors of the two economies.

The NIRA system is an extension of two existing macromodels. It is based on the most recent version of a large-scale model of the US, the Wharton Annual and Industry Forecasting Model (Preston, 1972; WEFA Group, 1982), a traditional macromodel with an embedded flexible input-output system to determine activity, employment and prices at the sectoral level. The IUJTsukuba model is used for Japan, an even larger model with a similar sectoral disaggregation.

The US and Japanese models are linked directly through trade volumes and prices. Following the methodology of Project LINK, behavioral equations within each country model determine the country's real import demands and export prices; these then determine partner-country export volumes and import prices. Bilateral US-Japan imports are determined in a two-stage process. First, overall import demand for each industry is computed as a function of industry demand and the relative import price. For Japan, we have:

$$
M_{i}=f\left(\frac{P_{i}^{\mathrm{M}}}{P_{i}^{\mathrm{JA}}}, D_{i}, I V_{i}(-1)\right)
$$

Here $P_{i}^{\mathrm{M}}$ is the Japanese import price for industry $i, P_{i}^{\mathrm{JA}}$ is the price of domestic production, and $D_{i}$ is the final demand for industry output. The lagged inventory stock, $I V_{i}(-1)$, is included in some equations to reflect increased imports that may occur when existing inventories are insufficient to meet demand. In a second step, the US share of Japanese industry imports is computed as a function primarily of the relative price of US exports to total Japanese imports:

$$
\frac{M_{i}^{\mathrm{US}}}{M_{i}}=f\left(\frac{P_{i}^{\mathrm{US}}}{P_{i}^{\mathrm{M}}}\right)
$$

The resulting Japanese demand for imports from the US, $M_{i}^{\mathrm{US}}$, represents a part of industry export demand in the US model (along with demand originating in third countries, computed for more aggregate categories in the LINK model). Japanese exports are similarly computed as the sum of US and third-country demand for Japanese goods. A parallel linkage mechanism determines Japanese import prices as a weighted-average of US and other country export prices.

The behavioral trade equations and the system of bilateral linkages provide the central channel for the transmission of economic effects between the two economies and with the rest of the world (RoW). Within the US-Japan model, these trade linkages feed directly into each model's input-output structure, so 
that changes in imports and exports directly affect final demand for industry output and the indirect demand for the production of other industries. Output for industry $i$ is given by

$$
X_{i}=F_{i}+E_{i}-M_{i}+\sum_{j} X_{i j}
$$

where $F_{i}$ is the domestic final demand, $E_{i}-M_{i}$ the net export demand, and $\Sigma_{j} X_{i j}$ the intermediate goods demand of other sectors. Trade price and quantity changes at the industry level are also aggregated up to help determine key macroeconomic variables in the model.

By integrating the US-Japan model into the LINK system, we are able to capture the macroeconomic linkages between these two economies and the rest of the world. However, trade links to the RoW are modeled only at the fourcategory level of the LINK model, and are then allocated proportionately across the detailed sectors of the US and Japanese models. Similarly, exports to the RoW are determined as fixed shares of world demand, as in other LINK country models. This means we are not able to compete between the US and Japan in third-country markets.

The NIRA model solution determines a globally consistent pattern of merchandise trade. ${ }^{8}$ Trade adjustment is accomplished through national economic developments or policy changes that alter import demands, trade prices, or trade shares (for the US and Japan). For the most part, the automatic adjustment mechanisms described above are not modeled. For the short-to-medium term horizon of the analysis, trade prices are assumed to be set by exporters and do not move to equilibrate trade. Exchange rates are currently treated as exogenous. Addition of an endogenous exchange rate subsystem would allow us to evaluate the yen's inertia in the face of growing current account surpluses, and prospects for further appreciation. But such a system would be difficult to implement because of the need to deal with asset holding decisions that are linked not just to relative rates of return but also to the balance sheet position of the Japanese financial system.

Given an assumed change in exchange rate paths or other macroeconomic policies, absorption and relative price movements induce changes in trade positions largely as described by the elasticity-absorption approach. Income and price elasticities of trade equations influence the extent of trade adjustment, as do the multiplier properties of the country models and the nature of inter-industry linkages. Under a yen appreciation, Japanese export price equations incorporate varying degrees of pricing-to-market behavior, limiting the extent of actual relative price change. Changes in national price levels create

\footnotetext{
${ }^{8}$ Other elements of the current account are modeled independently in the US, Japan and some other country models, but these flows may not move in a manner that is consistent across countries.
} 
real money balance and wealth effects that further affect absorption and trade balance adjustment.

\subsection{Macroadjustment simulations}

We evaluate macroeconomic policies for reducing the Japanese trade surplus using forecast simulations of the NIRA model. The simulation analysis is conducted by first establishing a baseline forecast simulation, and then re-solving the model with one or more exogenous policy changes. Simulation results are then reported as deviations from the baseline path. We describe characteristics of the baseline forecast below. We then present results for two alternative trade adjustment simulations: the 1993 yen appreciation, and the yen appreciation combined with a domestic Japanese fiscal stimulus.

\subsubsection{The baseline simulation}

The baseline forecast simulation, shown in Table 1, reflects economic developments in the US, Japan and world economies through early 1993, with forecasts for the rest of the decade broadly consistent with the consensus view of that time. (See Project LINK, 1993.) For the Japanese economy, the forecast reflects the sharp slowdown that occurred in 1992, followed by a recovery (more than a bit premature in our forecast, considering developments in 1993-1995) with the growth rate of gross national product (GNP) tending to the $3.5 \%$ per year rate, somewhat lower than for past decades. Inflation remains low to nonexistent, ranging from $0 \%$ to $2 \%$ generally, and with slow growth the unemployment rate edges up slightly toward $4 \%$ late in the decade.

The historically anemic economy and continuing strong export growth to the US, Asia, and other regions means the trade surplus continues to widen. Japanese real exports grow at a better than $5 \%$ average rate, real imports at a $3 \%$ rate, so that the real trade balance deficit expands to $4 \%$ of GNP by 1999 . The current account balance in dollars rises from $\$ 123$ billion to nearly $\$ 190$ billion over the forecast horizon. The baseline does not reflect the yen surge since 1993, but rather assumes a modest $1.5 \%$ average annual rate of yen appreciation between 1993 and 1999.

For the US, the simulation shows the cyclical recovery of 1993-1994 and then a normal growth path averaging $2.4 \%$ GNP growth per year. The inflation rate ranges between $3 \%$ and $5 \%$ annually. The unemployment rate remains in the $6-7 \%$ range. With relatively robust growth in the US and abroad, and no significant change in the overall value of the dollar, real US exports and imports grow at about the same $4.5 \%$ rate, so that the balance of trade on goods and services stays in the $\$ 40$ billion deficit range, and the current account deficit remains under $\$ 90$ billion. Because of the robust 
Table 1

US-Japan-world baseline forecast

\begin{tabular}{|c|c|c|c|c|c|c|}
\hline & 1992 & 1993 & 1994 & 1995 & 1999 & $\begin{array}{l}1992-1999 \\
\text { Average } \\
\text { growth rate }\end{array}$ \\
\hline \multicolumn{7}{|l|}{ Japan } \\
\hline GNP(80 Y billion) & 380408.0 & 391877.0 & 404959.0 & 416800.0 & 497910.0 & 3.6 \\
\hline Growth Rate (\%) & 1.5 & 3.0 & 3.3 & 2.9 & 5.1 & \\
\hline Normal GNP(Yb.) & 465258.0 & 473213.0 & 491553.0 & 519910.0 & 633875.0 & 4.2 \\
\hline Cons. price inflation $(\%)$ & 0.3 & 0.1 & 1.6 & 3.0 & 1.7 & $1.6^{*}$ \\
\hline Unemployment rate $(\%)$ & 3.1 & 3.3 & 3.4 & 3.6 & 4.0 & 3.6 \\
\hline $\mathrm{Y} / \mathrm{S}$ exchange rate & 128.8 & 126.9 & 125.1 & 123.2 & 116.1 & -1.9 \\
\hline \multicolumn{7}{|l|}{ Real trade bal. } \\
\hline G\&S (80 Yb.) & 2557.0 & 5976.0 & 7735.0 & 7003.0 & 19735.0 & $10327.5^{*}$ \\
\hline Exports & 75793.0 & 79992.0 & 84482.0 & 85960.0 & 111826.0 & 5.3 \\
\hline Imports & 73236.0 & 74016.0 & 76746.0 & 78957.0 & 92091.0 & 3.0 \\
\hline Nominal trade bal. (Yb.) & 16121.0 & 17864.0 & 18904.0 & 20587.0 & 22088.0 & $20139.3^{*}$ \\
\hline Current account (Sb.) & 123.0 & 138.6 & 149.1 & 165.0 & 188.2 & $163.2^{*}$ \\
\hline \multicolumn{7}{|l|}{ United States } \\
\hline GNP (72\$ billion) & 1911.6 & 1968.5 & 2025.0 & 2081.4 & 2281.2 & 2.4 \\
\hline Growth rate $(\%)$ & 1.2 & 3.0 & 2.9 & 2.8 & 2.4 & \\
\hline Nominal GNP(\$b.) & 5861.6 & 6218.9 & 6578.4 & 7074.4 & 9343.3 & 6.5 \\
\hline Cons. price inflation $(\%)$ & 2.4 & 3.5 & 3.4 & 5.3 & 4.2 & $4.3^{*}$ \\
\hline Unemployment rate $(\%)$ & 7.1 & 7.3 & 6.7 & 6.5 & 7.0 & 6.7 \\
\hline W. ave. exch. rate & 98.9 & 98.7 & 98.8 & 99.0 & 99.4 & 0.1 \\
\hline \multicolumn{7}{|l|}{ Real trade bal. } \\
\hline$G \& S(72 \$ b)$. & -24.2 & -24.5 & -24.6 & -25.3 & -41.1 & $-29.8^{*}$ \\
\hline Exports & 194.7 & 204.9 & 215.1 & 224.5 & 260.5 & 4.4 \\
\hline Imports & 218.9 & 229.3 & 239.6 & 249.8 & 301.6 & 4.7 \\
\hline Current account (\$b.) & -65.4 & -58.4 & -60.1 & -63.4 & -89.4 & $-69.1^{*}$ \\
\hline \multicolumn{7}{|l|}{ World } \\
\hline Nominal exports (\$b.) & 3882.8 & 4226.8 & 4586.8 & 4964.6 & 6758.0 & 8.3 \\
\hline Other indust. countries & 1960.1 & 2134.7 & 2318.6 & 2510.7 & 3444.6 & 8.5 \\
\hline Developing countries & 820.5 & 883.2 & 951.9 & 1020.7 & 1342.2 & 7.7 \\
\hline Real exports (70\$b.) & 904.7 & 962.4 & 1015.1 & 1067.6 & 1306.3 & 5.4 \\
\hline
\end{tabular}

*Average level of series.

performance of the US service sector, these figures mask deterioration in the merchandise trade deficit, which exceeds $\$ 160$ billion by the decade's end.

\subsubsection{Yen appreciation}

Between January and August 1993, the Yen appreciated significantly against major currencies; against the dollar, the yen rose from about 126 yen per dollar to 104 yen per dollar, a change of $17 \%$. Since then, it has, of course, 
appreciated further by an almost equal amount in percentage terms. ${ }^{9}$ Such a substantial increase in the value of the yen may have the potential to significantly reduce the trade surplus, perhaps after a prolonged J-curve improvement. Here, we have imposed the yen appreciation as an exogenous shift in the yen/dollar exchange rate, so that we can evaluate its potential for reducing the trade imbalance. ${ }^{10}$

Table 2 shows the impact of the yen appreciation on important macro variables in Japan, the US and the rest of the world. Table 3 shows regional changes in merchandise trade flows, and Table 4 reports employment and output effects in selected industries. Unless indicated, the figures given represent differences and percent differences from the baseline model simulation. Looking first at the Japan panel of Table 1, the appreciation is seen to make modest headway in reducing the Japanese surplus. After a J-curve improvement of about $\$ 1$ billion in 1993 , the Japanese merchandise trade balance declines steadily so that it is $\$ 19$ billion below baseline levels by 1999 . Because of positive valuation effects on service exports, the service balance rises moderately, so that the broader current account falls by $\$ 13$ billion over the forecast horizon.

These limited changes in the dollar trade balance mask more dramatic adjustments in yen-denominated flows. Measured in yen, the balance on goods and services (including factor income/receipts) is $¥ 4.7$ trillion lower by 1999 , a reduction of $21 \%$. Real exports decline nearly $10 \%$, contributing to a sharp reduction in the GNP growth rate. These significant adjustments in yen terms are nearly overcome by the large positive valuation effects associated with revaluing the huge initial surplus in now-smaller dollars.

While Japanese real exports fall dramatically, real import demand is little different from the baseline. Imports rise less than $1.5 \%$ in current dollars, and actually fall slightly in real terms. By comparison, US imports fall by a full $2.4 \%$ even though the weighted-average dollar is only $4 \%$ lower. This result comes from a combination of limited Japanese import price responsiveness and from the negative effects on import demand of falling Japanese economic activity.

The importance of trade price responsiveness for trade adjustment was emphasized in the theoretical section, above. Like many other studies of Japanese trade, behavioral import equations in our model have small estimated price

\footnotetext{
${ }^{9}$ However, just prior to this writing (mid-1995) the yen swung sharply lower in response to coordinated intervention by the central banks of Japan, the US and Germany, perhaps also correcting earlier overshooting in the positive direction.

${ }^{10}$ Because the yen/dollar exchange rate is adjusted directly, without changing underlying Japanese or US monetary policy, the scenario should be viewed as a nonpolicy appreciation resulting, for example, from a change in investors' expectations or fundamental asset preferences. Note that since the dollar is the numeraire currency for the LINK model, the simulated change represents a $17 \%$ appreciation of the yen against all currencies.
} 
Table 2

Macroeconomic and trade effects of yen appreciation

\begin{tabular}{|c|c|c|c|c|c|}
\hline & 1993 & 1994 & 1995 & 1996 & 1999 \\
\hline \multicolumn{6}{|l|}{ Japan } \\
\hline GNP( 80 Y billion) & -5586.2 & -13897.2 & -17210.5 & -18386.5 & -20462.7 \\
\hline$\%$ Difference & -1.4 & -3.4 & -4.1 & -4.3 & -4.1 \\
\hline Nominal GNP (Yb.) & -7635.9 & -20572.7 & -29495.6 & -33646.6 & -40274.9 \\
\hline Cons. price inflation $(\%)$ & -1.3 & -2.9 & -3.5 & -3.8 & -6.1 \\
\hline $\mathrm{Y} / \$$ exchange rate $(\%)$ & -9.0 & -17.1 & -17.1 & -17.1 & -17.1 \\
\hline Real trade bal. G\&S ( $80 \mathrm{Yb}$.) & -3933.1 & -8097.2 & -7747.2 & -7965.6 & -10278.1 \\
\hline Exports & -3891.9 & -8035.4 & -7970.6 & -8539.0 & -10690.3 \\
\hline$\%$ Difference & -4.9 & -9.5 & -9.3 & -9.5 & -9.6 \\
\hline Imports & 41.2 & 61.8 & -223.4 & -573.4 & -412.2 \\
\hline$\%$ Difference & 0.1 & 0.1 & -0.3 & -0.7 & -0.4 \\
\hline Nominal trade bal. (Yb.) & -1487.0 & -3332.0 & -4046.0 & -4207.0 & -4685.0 \\
\hline Current account (\$b.) & 2.4 & -0.9 & -5.0 & -6.6 & -13.2 \\
\hline Nominal merchandise balance & 1.2 & -2.1 & -8.6 & -11.0 & -19.4 \\
\hline Nominal service/other balance & 1.2 & 3.0 & 3.6 & 3.4 & 6.2 \\
\hline \multicolumn{6}{|l|}{ United States } \\
\hline GNP ( $72 \$$ billion $)$ & 0.9 & 4.1 & 6.9 & 8.8 & 9.0 \\
\hline \%Difference & 0.0 & 0.2 & 0.3 & 0.4 & 0.4 \\
\hline Nominal GNP (\$b.) & 3.7 & 18.4 & 38.7 & 62.6 & 124.9 \\
\hline Cons. price inflation $(\%)$ & 0.1 & 0.3 & 0.4 & 0.6 & 1.1 \\
\hline W. ave. exch. rate $(\%)$ & 1.9 & 3.8 & 3.8 & 3.8 & 3.8 \\
\hline Real trade bal. G\&S (72\$b.) & 1.5 & 3.3 & 3.9 & 5.1 & 6.6 \\
\hline Exports & 0.4 & 0.6 & 0.3 & 0.0 & -0.8 \\
\hline$\%$ Difference & 0.2 & 0.3 & 0.1 & 0.0 & -0.3 \\
\hline Imports & -1.1 & -2.6 & -3.6 & -5.1 & -7.3 \\
\hline$\%$ Difference & -0.5 & -1.1 & -1.5 & -1.9 & -2.4 \\
\hline Current account (\$b.) & -3.0 & -3.9 & 0.9 & 4.3 & 11.6 \\
\hline Nominal merchandise balance & -1.4 & -0.7 & 4.1 & 7.9 & 14.9 \\
\hline Nominal service/other balance & -1.6 & -3.2 & -3.2 & -3.6 & -3.3 \\
\hline \multicolumn{6}{|l|}{ World } \\
\hline Gross national product $(\%)$ & 0.0 & -0.1 & -0.1 & -0.1 & -0.2 \\
\hline Real exports $(70 \$ b)$. & -1.5 & -3.0 & -4.5 & -6.6 & -8.8 \\
\hline Nominal exports $(\$ b$. $)$ & 18.5 & 34.2 & 25.2 & 23.1 & 30.9 \\
\hline
\end{tabular}

Note: Figures are differences and percent differences from the baseline simulation.

elasticities - the implied weighted-average elasticity for all goods is just -0.2 . With the decline in relative import prices of $12 \%$, we can expect to see at most a $2.5 \%$ increase in real imports. Even this limited import response does not materialize, because of the negative income effects of yen appreciation. Led by the drop in exports, GNP declines by $4 \%$ by 1999 . The deflationary effect of this drop in demand more than offsets the increased price competitiveness of imports so that real imports remain near baseline levels. 
Table 3

Effect of yen appreciation on regional merchandise trade flows

\begin{tabular}{|c|c|c|c|c|c|c|}
\hline & 1993 & 1994 & 1995 & 1996 & 1999 & $\begin{array}{l}1999 \text { Percent } \\
\text { Difference }\end{array}$ \\
\hline \multicolumn{7}{|l|}{ Japan } \\
\hline Exports & 3.3 & 1.7 & -5.5 & -8.5 & -14.7 & -2.2 \\
\hline Imports & 2.1 & 3.8 & 3.1 & 2.5 & 4.7 & 1.2 \\
\hline Balance & 1.2 & -2.1 & -8.6 & -11.0 & -19.4 & \\
\hline Exports to the US & 0.9 & -2.8 & -9.5 & -12.8 & -20.2 & -2.2 \\
\hline Imports from the US & 0.7 & 1.2 & 0.8 & 0.7 & 1.5 & 1.5 \\
\hline Balance & 0.3 & -4.0 & -10.3 & -13.5 & -21.7 & \\
\hline \multicolumn{7}{|l|}{ United States } \\
\hline Exports & 2.6 & 5.1 & 4.7 & 5.0 & 8.0 & 1.0 \\
\hline Imports & 4.0 & 5.9 & 0.5 & -2.9 & -6.9 & -0.7 \\
\hline Balance & -1.4 & -0.7 & 4.1 & 7.9 & 14.9 & \\
\hline Exports to Japan & 0.7 & 1.2 & 0.8 & 0.7 & 1.5 & 1.5 \\
\hline Imports from Japan & 0.9 & -2.8 & -9.5 & -12.9 & -20.3 & -8.3 \\
\hline Balance & -0.3 & 4.0 & 10.3 & 13.5 & 21.8 & \\
\hline \multicolumn{7}{|l|}{$\begin{array}{l}\text { Other industrailized } \\
\text { countries }\end{array}$} \\
\hline Exports & 8.9 & 18.3 & 17.1 & 17.5 & 23.5 & 0.7 \\
\hline Imports & 6.7 & 12.5 & 10.9 & 11.5 & 15.1 & 0.4 \\
\hline Balance & 2.2 & 5.8 & 6.2 & 6.0 & 8.4 & \\
\hline \multicolumn{7}{|l|}{ Developing economies } \\
\hline Exports & 3.1 & 7.8 & 7.7 & 7.6 & 11.5 & 0.9 \\
\hline Imports & 6.0 & 11.4 & 10.3 & 11.6 & 15.8 & 1.3 \\
\hline Balance & -3.0 & -3.6 & -2.5 & -4.0 & -4.3 & \\
\hline \multicolumn{7}{|l|}{$\begin{array}{l}\text { Former cent.-planned } \\
\text { economies }\end{array}$} \\
\hline Exports & 1.8 & 3.8 & 3.7 & 3.8 & 5.2 & 1.1 \\
\hline Imports & 2.3 & 4.5 & 4.0 & 4.2 & 4.8 & 1.3 \\
\hline Balance & -0.5 & -0.6 & -0.3 & -0.4 & 0.4 & \\
\hline World total exports & 18.5 & 34.2 & 25.2 & 23.1 & 30.9 & 0.5 \\
\hline
\end{tabular}

Note: Figures are differences from baseline simulation levels in billions of current dollars. For 1999, the percent difference from the baseline is also reported.

The important offsetting effect of economic contraction on trade balance adjustment was anticipated by absorption school writers, and has been noted for Japan in previous studies. Yoshitomi (1991) points out that "general equilibrium" trade price elasticities are much smaller than the partial equilibrium elasticities of import equations, so that, "the potential external account [deterioration] due to export and import price changes alone is considerably offset by endogenized changes in incomes and prices" (p. 129). This point has also been made by McKinnon (1993) and others in their recent critiques of a "weak dollar policy" for reducing the US-Japan trade imbalance. 
Table 4

Effect of yen appreciation on selected industries

\begin{tabular}{|c|c|c|c|c|}
\hline & \multicolumn{2}{|c|}{ Difference in gross output $(\%)$} & \multicolumn{2}{|c|}{ Difference in employment (thous.) } \\
\hline & 1994 & 1999 & 1994 & 1999 \\
\hline \multicolumn{5}{|l|}{ Japan } \\
\hline Rubber products & -13.5 & -13.2 & -5.8 & -9.5 \\
\hline Chemicals & -3.1 & -4.2 & -2.6 & -1.2 \\
\hline Fabricated metal products & -4.0 & -4.0 & -12.9 & -14.1 \\
\hline Nonelectrical machinery & -8.7 & -9.8 & -51.5 & -79.6 \\
\hline Electrical machinery & -5.0 & -5.2 & -41.3 & -50.6 \\
\hline Automobiles & -6.5 & -10.5 & -4.8 & -35.3 \\
\hline Housing, construction & -1.9 & -2.3 & -32.7 & -84.5 \\
\hline Wholelsale, retail & -1.1 & -2.7 & -8.3 & -107.6 \\
\hline Personal services & -0.5 & -1.6 & -62.9 & -238.8 \\
\hline Total & -2.1 & -2.8 & -323.9 & -821.6 \\
\hline \multicolumn{5}{|l|}{ United States } \\
\hline Mining & 0.4 & 0.7 & 0.0 & 0.0 \\
\hline Rubber and plastics & 0.5 & 0.7 & 2.6 & 7.2 \\
\hline Primary metals & 0.7 & 1.6 & 4.5 & 25.1 \\
\hline Fabricated metal products & 0.6 & 1.0 & 8.0 & 29.7 \\
\hline Nonelectrical machinery & 0.6 & 0.6 & 17.7 & 44.9 \\
\hline Electrical machinery & 1.1 & 3.0 & 13.5 & 44.7 \\
\hline Automobiles & 0.9 & 3.4 & 3.7 & 23.5 \\
\hline Transportation services & 0.3 & 0.4 & 4.1 & 19.1 \\
\hline Wholesale, retail & 0.1 & 0.2 & 6.4 & 65.2 \\
\hline Personal services & 0.1 & 0.3 & 8.0 & 100.9 \\
\hline Manufactures total & 0.5 & 1.0 & 90.0 & 415.7 \\
\hline
\end{tabular}

Note: Figures are differences from baseline values. For real gross output, the percent difference is given; for employment, the difference in thousands of employees is reported.

Larger estimated price elasticities would generate bigger trade changes under the yen appreciation. In recent years, some economists have speculated that Japanese import demand might indeed have become more price sensitive, as a result of changes in consumer preferences, and liberalization of domestic and import markets. Our trade model is based on data through only the mid-1980s, so an updated trade model could very well yield higher elasticity estimates and more responsive imports. However, the evidence on elasticity changes in Japanese trade suggests that while import demand may be more price elastic, exports have likely become less so, with the net effect that trade adjustment is more limited than in the past (see for example, Moriguchi, 1993; Ochi and Utsunomiya, 1993).

Table 3 shows changes in US-Japan bilateral merchandise trade and in merchandise trade by other world regions. A result worth noting is that the 
sharp decline in Japanese exports is completely (indeed more than completely) accounted for by the decline in exports to the US market. That the US-Japan bilateral balance sees most of the trade adjustment is no accident. In part, this is the result of the high price sensitivity of US import demand and the relative size of the US market. But it also stems from the structure of the NIRA model system. As noted above, RoW imports are modeled using standard LINK methodology which applies a fixed trade share matrix to allocate a vector of world import demands across exporting countries. As a result, RoW countries cannot substitute away from Japanese imports when the yen appreciates. In fact higher dollar Japanese export prices actually raise their import bill, reflected in the small observed increases in Japanese dollar exports to RoW countries. For many RoW countries, particularly in East Asia, this may not be unrealistic.

On the strength of its sharp decline in merchandise imports from Japan and increased export competitiveness, the US achieves a $\$ 15$ billion dollar improvement in its merchandise trade balance by the decade's end. US importers shift decisively away from Japanese suppliers, so that most of the $\$ 20$ billion drop in imports from Japan is replaced by imports from RoW countries. The resulting improvement in the bilateral trade balance between the US and Japan is almost $\$ 22$ billion. US trade balance gains result in general expansion of the economy; GNP is one-half percent higher by 1999.

An important point from a political perspective is that the effects of yen appreciation are not distributed uniformly across industries in the Japanese and US economies. As shown in Table 4, export-dependent Japanese sectors like automobiles and machinery are particularly hard hit, and their suppliers (for example rubber products and metals) also suffer. Many of these same sectors expand in the US as American producers gain market share from Japanese exporters. Overall, employment falls by over 800000 workers in Japan, while rising half that in the US.

\subsubsection{Yen appreciation with fiscal stimulus}

Fiscal policy has the potential to alter the trade balance by directly affecting the level of expenditure relative to income, or net national savings relative to investment. Additional fiscal expansion in Japan might be a sensible counterpart to adjustment through yen appreciation, because it could help to offset the adverse domestic macroeconomic consequences of appreciation while contributing to further surplus reduction.

Fiscal stimulus has been at the center of the Japanese economic policy debate in recent years. With the Japanese slowdown and the surge in the trade surplus, there has been increasing pressure from both inside and outside Japan for a strong fiscal response. Several packages of spending increases and other measures have been implemented since 1992; the largest of these, enacted in February 1994 , included $¥ 5.5$ trillion in income tax cuts, significant increases 
in public works spending and programs to support the land market and banking institutions. The yen appreciation has strengthened the hand of those advocating significant expansionary policies to prevent a more severe economic downturn, though officials have been reluctant to extend more than modest temporary fiscal stimulus measures.

In this section, we simulate the adoption of a fiscal stimulus together with the yen appreciation analyzed above. The stimulus applied has been chosen purposely as the stimulus needed to just offset the adverse macroeconomic

Table 5

Macroeconomic and trade effects of yen appreciation with fiscal stimulus

\begin{tabular}{|c|c|c|c|c|c|}
\hline & 1993 & 1994 & 1995 & 1996 & 1999 \\
\hline \multicolumn{6}{|l|}{ Japan } \\
\hline GNP (80Y billion) & 600.4 & 748.1 & 560.6 & 1066.4 & -415.9 \\
\hline$\%$ Difference & 0.2 & 0.2 & 0.1 & 0.2 & -0.1 \\
\hline Nominal GNP (Yb.) & -1755.6 & -5722.1 & -9311.7 & -9250.3 & -8984.9 \\
\hline Cons. price inflation $(\%)$ & -1.6 & -3.4 & -3.7 & -3.8 & -3.5 \\
\hline $\mathrm{Y} / \$$ exchange rate $(\%)$ & -9.0 & -17.1 & -17.1 & -17.1 & -17.1 \\
\hline Read trade bal. G\&S ( $80 \mathrm{Yb}$.) & -4402.2 & -9746.0 & -10180.9 & -10721.1 & -13571.2 \\
\hline Exports & -3850.8 & -8094.7 & -8197.2 & -8845.2 & -11045.4 \\
\hline$\%$ Difference & -4.8 & -9.6 & -9.5 & -9.8 & -9.9 \\
\hline Imports & 551.4 & 1651.2 & 1983.7 & 1875.9 & 2525.7 \\
\hline$\%$ Difference & 0.7 & 2.2 & 2.5 & 2.3 & 2.7 \\
\hline Nominal trade bal. (Yb.) & -1815.0 & -4247.0 & -5272.0 & -5594.0 & -6451.0 \\
\hline Current account (\$b.) & 0.0 & -6.1 & -14.0 & -17.7 & -26.2 \\
\hline Nominal merchandise balance & -1.0 & -8.6 & -16.9 & -20.3 & -31.3 \\
\hline Nominal service/other balance & 1.0 & 2.5 & 2.9 & 2.6 & 5.1 \\
\hline \multicolumn{6}{|l|}{ United States } \\
\hline GNP ( $72 \$$ billion $)$ & 1.4 & 5.5 & 9.0 & 11.3 & 11.5 \\
\hline$\%$ Difference & 0.1 & 0.3 & 0.4 & 0.5 & 0.5 \\
\hline Nominal GNP (\$b.) & 5.3 & 23.6 & 48.3 & 77.3 & 154.1 \\
\hline Cons. price inflation $(\%)$ & 0.1 & 0.3 & 0.5 & 0.7 & 1.3 \\
\hline W. ave exch. rate $(\%)$ & 1.9 & 3.8 & 3.8 & 3.8 & 3.8 \\
\hline Real trade bal. $G \& S(72 \$ b)$. & 1.6 & 3.8 & 4.7 & 6.0 & 7.6 \\
\hline Exports & 0.6 & 1.3 & 1.2 & 0.9 & 0.1 \\
\hline$\%$ Difference & 0.3 & 0.6 & 0.5 & 0.4 & 0.1 \\
\hline Imports & -1.0 & -2.5 & -3.6 & -5.1 & -7.4 \\
\hline$\%$ Difference & -0.4 & -1.0 & -1.4 & -1.9 & -2.5 \\
\hline Current account (\$b.) & -2.0 & -1.3 & 4.2 & 8.1 & 16.4 \\
\hline Nominal merchandise balance & -0.7 & 1.0 & 6.4 & 10.4 & 18.2 \\
\hline Nominal service/other balance & -1.3 & -2.3 & -2.2 & -2.3 & -1.8 \\
\hline \multicolumn{6}{|l|}{ World } \\
\hline Gross national product $(\%)$ & 0.1 & 0.2 & 0.2 & 0.3 & 0.2 \\
\hline Real exports (70\$b.) & -0.7 & -1.1 & -2.0 & -3.8 & -6.2 \\
\hline Nominal exports (\$b.) & 21.4 & 44.0 & 41.3 & 42.7 & 56.9 \\
\hline
\end{tabular}

Note: Figures are differences and percent differences from the baseline simulation. 
impact of the yen rise. Real Japanese government investment is raised by about $¥ 6$ trillion per year (about $1.5 \%$ of GNP), sufficient stimulus to return real output roughly to its pre-appreciation path.

Tables 5 and 6 show the macroeconomic and trade effects of the yen appreciation and fiscal stimulus. The fiscal policy leads to some additional reduction in the trade surplus. The spending increase offsets the contractionary income effect of yen appreciation on import demand, so that real imports of goods and services rise by $2.7 \%$. The dollar Japanese merchandise trade balance falls an additional $\$ 12$ billion. so that it is $\$ 31$ billion below baseline levels by the end of the century. US exporters see $\$ 4$ billion of this increased demand, so that the bilateral US trade balance deficit with Japan shrinks by that additional increment.

Table 6

Effect on regional merchandise trade flows of yen appreciation with fiscal stimulus

\begin{tabular}{|c|c|c|c|c|c|c|}
\hline & 1993 & 1994 & 1995 & 1996 & 1999 & $\begin{array}{l}1999 \text { Percent } \\
\text { Difference }\end{array}$ \\
\hline \multicolumn{7}{|l|}{ Japan } \\
\hline Exports & 3.3 & 2.0 & -4.7 & -7.5 & -13.4 & -2.1 \\
\hline Imports & 4.2 & 10.6 & 12.2 & 12.8 & 17.9 & 4.4 \\
\hline Balance & -1.0 & -8.6 & -16.9 & -20.3 & -31.3 & \\
\hline Exports to the US & 0.8 & -3.0 & -9.6 & -13.1 & -20.8 & -8.5 \\
\hline Imports from the US & 1.3 & 3.2 & 3.5 & 3.5 & 4.9 & 4.7 \\
\hline Balance & -0.5 & -6.2 & -13.1 & -16.6 & -25.7 & \\
\hline \multicolumn{7}{|l|}{ United States } \\
\hline Exports & 3.4 & 7.6 & 8.3 & 9.2 & 13.5 & 1.7 \\
\hline Imports & 4.1 & 6.7 & 1.9 & -1.3 & -4.7 & -0.5 \\
\hline Balance & -0.7 & 1.0 & 6.4 & 10.4 & 18.2 & \\
\hline Exports to Japan & 1.3 & 3.2 & 3.5 & 3.4 & 4.9 & 4.7 \\
\hline Imports from Japan & 0.8 & -3.0 & -9.7 & -13.2 & -20.8 & -8.4 \\
\hline Balance & 0.5 & 6.2 & 13.1 & 16.6 & 25.7 & \\
\hline \multicolumn{7}{|c|}{ Other industrailized countries } \\
\hline Exports & 9.7 & 21.6 & 22.7 & 24.6 & 32.3 & 0.9 \\
\hline Imports & 6.8 & 13.8 & 13.5 & 15.1 & 19.7 & 0.5 \\
\hline Balance & 2.8 & 7.8 & 9.2 & 9.5 & 12.6 & \\
\hline \multicolumn{7}{|l|}{ Developing economies } \\
\hline Exports & 4.3 & 11.3 & 13.4 & 14.6 & 20.7 & 1.5 \\
\hline Imports & 6.1 & 12.6 & 12.9 & 15.4 & 22.1 & 1.8 \\
\hline Balance & -1.8 & -1.3 & 0.5 & -0.8 & -1.4 & \\
\hline \multicolumn{7}{|c|}{ Former cent.-planned economies } \\
\hline Exports & 2.0 & 4.7 & 5.2 & 5.6 & 7.6 & 1.6 \\
\hline Imports & 2.5 & 5.2 & 5.3 & 5.8 & 6.9 & 1.8 \\
\hline Balance & -0.4 & -0.4 & -0.1 & -0.2 & 0.7 & \\
\hline World total exports & 21.4 & 44.1 & 41.3 & 42.7 & 56.9 & 0.8 \\
\hline
\end{tabular}

Note: Figures are differences from baseline simulation levels in billions of current dollars. For 1999, the percent difference from the baseline is also reported. 
While restoring aggregate output to its original baseline path, the general fiscal stimulus is not able to prevent losses in Japan to heavily trade-dependent industries. In Table 7, autos and machinery experience net declines in output and employment. Other industries, particularly construction and service sectors benefit more from increased demand and see output and employment gains.

The moderate fiscal stimulus imposed in this simulation generates only limited additional improvement in the trade imbalance. A larger stimulus designed to jump start the Japanese economy could provide larger trade adjustment gains, at least in the short run. Our effects likely underestimate trade balance changes under the stimulus because they do not permit additional endogenous yen adjustment. Once the stimulative effect of fiscal spending on Japanese interest rates is taken into account, we might expect to see still further appreciation of the yen, and some additional trade rebalancing.

Effect on selected industries of yen appreciation with fiscal stimulus

\begin{tabular}{|c|c|c|c|c|}
\hline & \multicolumn{2}{|c|}{ Difference in gross output $(\%)$} & \multicolumn{2}{|c|}{ Difference in employment (thous.) } \\
\hline & 1994 & 1999 & 1994 & 1999 \\
\hline \multicolumn{5}{|l|}{ Japan } \\
\hline Rubber products & -10.2 & -11.3 & -3.9 & -7.1 \\
\hline Chemicals & -1.1 & -1.9 & 0.3 & 1.8 \\
\hline Fabricated metal products & 1.1 & 1.8 & -0.1 & 0.6 \\
\hline Nonelectrical machinery & -5.4 & -5.7 & -34.0 & -51.3 \\
\hline Electrical machinery & 1.4 & 0.6 & 12.3 & 11.3 \\
\hline Automobiles & -3.9 & -7.8 & -2.9 & -25.1 \\
\hline Housing, construction & 6.8 & 5.3 & 52.2 & 87.6 \\
\hline Wholelsale, retail & 0.4 & -0.3 & 6.1 & -10.5 \\
\hline Personal services & 0.9 & 1.0 & -42.3 & 1.2 \\
\hline Total & 1.0 & 0.8 & 0.5 & 50.1 \\
\hline \multicolumn{5}{|l|}{ United States } \\
\hline Mining & 0.6 & 0.8 & 0.0 & 0.0 \\
\hline Rubber and plastics & 0.6 & 0.9 & 3.1 & 9.1 \\
\hline Primary metals & 0.8 & 1.8 & 5.8 & 30.0 \\
\hline Fabricated metal products & 0.7 & 1.1 & 9.1 & 33.2 \\
\hline Nonelectrical machinery & 0.7 & 0.6 & 20.2 & 53.7 \\
\hline Electrical machinery & 1.2 & 3.3 & 15.0 & 48.6 \\
\hline Automobiles & 1.1 & 3.9 & 4.7 & 26.8 \\
\hline Transportation services & 0.4 & 0.6 & 6.2 & 25.8 \\
\hline Wholesale, retail & 0.1 & 0.3 & 15.9 & 101.8 \\
\hline Personal services & 0.1 & 0.4 & 12.8 & 134.0 \\
\hline Manufactures total & 0.6 & 1.1 & 122.5 & 540.2 \\
\hline
\end{tabular}

Note: Figures are differences from baseline values. For real gross output, the percent difference is given; for employment, the difference in thousands of employees is reported. 


\subsection{Comparison to previous studies}

Comparison of our results to those of other recent studies of Japanese trade balance adjustment are complicated by differences in analytical framework and scenario design. Unlike the present analysis, many studies use partial equilibrium export and import equation estimates to gauge trade balance adjustment. There are differences in the manner in which exchange rate change is assumed to occur, as well as the nature of fiscal stimuli. To our knowledge, there are also a relatively limited number of published studies that focus on Japanese adjustment, unlike the large number of studies looking at the problem from the US perspective. Ito (1994) looks at the contribution of several factors to recent movements in the Japanese balance of payments. Using a partial equilibrium trade model, he finds that a hypothetical movement of the yen from $125 ¥ / \$$ in 1989 to $100 ¥ / \$$ by late 1991 would have reduced the current account surplus by $\$ 25$ billion. This estimate is very close to that of Hooper and Marquez (1993), who estimate that every $10 \%$ yen appreciation reduces the surplus by $\$ 10$ billion after five years. Even larger estimates come from Cline (1993), who predicts a $\$ 4$ billion adjustment in the Japanese current account for every $1 \%$ appreciation of the yen.

Our estimates are about half as large as those of Ito, and Hooper and Marquez. We predict that the $17 \%$ yen appreciation of 1993 will reduce the real Japanese trade surplus by $¥ 8$ trillion (1980 yen) after four years, about $2 \%$ of baseline GNP, with the reduction in the dollar current account only $\$ 6.6$ billion over this time period. This result is actually very close to that obtained by Corker (1989). In counter-factual simulations for the late 1980s, he finds that a $40 \%$ appreciation of the yen yields a $¥ 9$ trillion reduction in the current account $(2.5 \%$ of GNP), but only a $\$ 3$ billion reduction in the dollar balance because of large offsetting J-curve valuation effects.

The range of trade adjustment estimates is considerable, with our results clearly at the low end among the studies discussed here. The variety of estimates of yen appreciation effects appears to be attributable in part to differences in estimated trade price elasticities across models, and to differences between partial and general equilibrium modeling approaches. Empirical studies of trade adjustment that ignore equilibrium reductions in economic activity accompanying yen appreciation will likely overestimate the extent of adjustment. In our model, these changes limit considerably the rise in Japanese imports and the consequent reduction of the Japanese current account.

The estimated trade adjustment from a Japanese fiscal expansion is similar in the present study and other recent analyses. We find that a $1.5 \%$ of GNP fiscal stimulus creates an additional half percent of GNP real trade balance reduction after four years, and an additional $\$ 11$ billion reduction in the Japanese current account. Balassa and Noland (1988) report Federal Reserve and Bank of Japan studies that find a $¥ 3$ trillion Japanese fiscal stimulus 
( $1 \%$ of gross domestic product, GDP, or about $\$ 20$ billion dollars at 1987 exchange rates) would reduce the Japanese surplus by $\$ 1.5-\$ 5.9$ billion. Their own estimate falls between these two figures. Allowing for economic growth and exchange rate changes since the late 1980 s, these estimates imply a $1 \%$ of GDP stimulus today would create about a $\$ 4-\$ 15$ billion Japanese current account reduction. Similarly, Cline (1989) estimates that $1 \%$ faster Japanese economic growth for the single year 1992 would reduce the trade surplus by $\$ 3.2$ billion (p. 211), and McKibben and Sachs (1991) estimate that a $1 \%$ of GDP stimulus would reduce the Japanese current account by $0.5 \%$ of GDP in real terms. In at least some of these studies, fiscal expansion leads to yen appreciation that reinforces trade balance adjustment; endogenous exchange rate adjustment is not modeled in the scenarios we have presented here.

\section{Conclusions}

In this paper we have described the development of the Japanese trade surplus and evaluated prospects for trade balance adjustment. By viewing the surplus problem in the light of theoretical models of international adjustment, we have identified sources of the surplus's stubborn persistence and prerequisites for its solution. Using simulations of the NIRA model of the US-JapanWorld economy, we have then measured the potential adjustment gains from exchange rate change and fiscal stimulus in Japan.

Exchange appreciation will be only moderately effective in reducing the Japanese trade surplus. Model simulations of the recent yen surge suggest the trade balance would fall by $\$ 19$ billion dollars below baseline levels by the decade's end as a result of the terms of trade improvement. While this change is not dramatic, the lion's share of this adjustment may occur in the politically sensitive US-Japan bilateral balance.

Fiscal expansion in Japan can also contribute to reducing the surplus. In fact, an accompanying fiscal stimulus is important if yen appreciation is to be fully effective. The general equilibrium impact of falling income limits the extent of trade adjustment under a yen appreciation. By combining appreciation with a general fiscal stimulus, gains in trade rebalancing can be achieved without adverse effects on GNP. In our simulation, a fiscal stimulus sufficient to maintain baseline economic growth rates would reduce the surplus an additional $\$ 12$ billion dollars by 1999 .

The appreciation of the yen to date, and a modest fiscal expansion, will clearly not eliminate the trade surplus problem. By our forecast, the Japanese current account balance would still rise to above $\$ 150$ billion by 1999 . Even with a stronger-than-expected cyclical recovery in Japan, the surplus might remain in the $\$ 80-\$ 100$ billion range. Additional macroeconomic adjustments would then be necessary. In particular, we would expect to see further substan- 
tial yen appreciation over the balance of the decade. Persisting foreign political pressure might spur further fiscal expansion in Japan as well.

A number of writers have questioned the potential for traditional macroeconomic solutions to the Japanese surplus problem. Fundamentally closed markets or hysteretic effects of past policies may thwart adjustment by exchange appreciation or fiscal stimulus. Certainly our simulations suggest that very large macropolicy changes would be necessary to close the trade gap. The alternatives to macroeconomic approaches involve structural change in $\mathbf{J a}$ pan's trade relationships with other countries. Some such changes are underway already, and account for significant growth of Japanese real imports in the past two years. On the demand side, retail market development and increased access for foreign goods is stimulating consumption of imports. On the supply side, Japanese firms are increasingly replacing domestic production with imports from low-cost production platforms in China and South East Asia. Additional measures to open Japanese markets, and continuing evolution of Japanese consumption/savings patterns, might be necessary to eliminate the remaining trade imbalance. ${ }^{11}$ Quantitative analyses of trade balance gains likely from these structural changes are needed as a counterpart to macroeconomic policy simulation studies.

\section{Acknowledgements}

Thanks to conference participants, Jaime Marquez, and an anonymous referee for helpful comments. Thanks also to the National Institute for Research Advancement, Japan, and the Ministry for International Trade and Industry, Japan, for financial support.

\section{References}

Adams, F. G., B. Gangnes and S. Shishido, 1993a, Economic activity, trade and industry in the US-Japan-world economy: A macromodel study of economic interactions (Praeger, Westport, Connecticut).

Adams, F. G., B. Gangnes and S. Shishido, 1993b, Macroeconomic and industry level implications of alternative macro, trade, and industry policies, Journal of Applied Input-Output Analysis $1(2), 46-81$.

Adams, F. G., B. Gangnes and S. Shishido, 1994, Macro and industry implications of voluntary export restraints on US-Japan trade, The World Economy 17, 737-757.

Alexander, S.S., 1952. Effects of a devaluation on a trade balance. IMF Staff Papers II, April, $263-278$.

\footnotetext{
"In other work, we have evaluated the macro and industry effects of increases in Japanese import volume (Adams et al., 1993b), and of voluntary export restraints (Adams et al., 1994).
} 
Artus, J.R. and M.D. Knight, 1984, Issues in the assessment of the exchange rates of industrial countries, Occasional Paper 29, International Monetary Fund.

Balassa, B. and M. Noland, 1988, Japan in the world economy (Institute for International Economics, Washington).

Baldwin, R., 1988, Hysteresis in import prices: The beachhead effect, American Economic Review $78,773-785$.

Bodkin, R.G., L.R. Klein and K. Marwah, 1991, A history of macroeconometric model-building (Edward Elgar, London).

Cline, W., 1989, US external adjustment and the world economy (Institute for International Economics, Washington).

Cline, W., 1993, How undervalued is the yen?, Institute for International Economics, Washington, mimeograph, February, as cited in C.F. Bergsten and M. Noland, 1993, Reconcilable differences? US -Japan economic conflict (Institute for International Economics, Washington).

Corker, R., 1989, External adjustment and the strong yen: Recent Japanese experience, IMF Staff Papers 36, 464-493.

Dixit, A., 1989, Hysteresis, import penetration, and exchange rate passthrough, Quarterly Journal of Economics 104(2), 205-229.

Dornbusch, R., 1973, Devaluation, money, and non-traded goods, The American Economic Review 62, 871-883.

Frenkel, J. and H.G. Johnson (eds.), 1976, The monetary approach to the balance of payments (The University of Toronto Press, Toronto).

Frenkel, J. and A. Razin, 1992, Fiscal policies and the world economy, 2nd edn. (MIT Press, Cambridge, MA).

Goldstein, M. and M.S. Khan, 1985, Income and price elasticities in foreign trade, Ch. 20, in: R.W. Jones and P.B. Kenen, eds., Handbook of international economics, Vol. 2 (North-Holland, Amsterdam) 1041-1105.

Hooper, P. and J. Marquez, 1993, Exchange rates, prices, and external adjustment in the United States and Japan, Board of Governors of the Federal Reserve System international finance discussion paper 456 .

Ito, T., 1994, On recent movements of Japanese current accounts and capital flows, Ch. 2, in: T. Ito and A. Krueger, eds., Macroeconomic linkage: Savings, exchange rates, and capital flows (University of Chicago press, Chicago) 31-52.

Klein, L.R., P. Pauly and P. Voisin, 1982, The world economy - a global model, Perspectives in Computing 2(2), 4-17.

Kouri, P., 1976, The exchange rate and the balance of payments in the short run and the long run: A monetary approach, Scandinavian Journal of Economics 78, 280-306.

Krugman, P., 1987, Pricing to market when the exchange rate changes, Ch.3, in: S. Arndt and J.D. Richardson, eds., Real-financial linkages among open economies (MIT Press, Cambridge, MA) 49-70.

Krugman, P., 1991, Has the adjustment process worked?, Policy analyses in international economics, Vol. 34 (Institute for International Economics, Washington)

LINK, Project, 1993, World outlook, March 10, 1993.

Machlup, F., 1939, The theory of foreign exchanges, Economica 6, 375-397.

McKibben, W. and J. Sachs, 1991, Global linkages: Macroeconomic interdependence and co-operation in the world economy (The Brookings Institution, Washington, DC).

McKinnon, R., 1993, Dollar and yen: The problem of financial adjustment between the United States and Japan, as cited in The Economist, October 2, 1993, 81.

Moriguchi, C., 1993, Managed trade and the Japan-US imbalance, paper presented at the World Project LINK meeting, Beijing, China, September.

NLI Research Institute, 1993, NLI research 59, 37. 
Obstfeld, M., 1981, Macroeconomic policy, exchange-rate dynamics, and optimal asset accumulation, Journal of Political Economy 89, 1142-1161.

Ochi, M. and K. Utsonomiya, 1993, The exchange rate and trade account adjustment in Japan, paper presented at the World Project LINK meeting, Beijing, China, September.

Pilbeam, K., 1992, International finance (Macmillan, London).

Preston, R.S., 1972, The Wharton annual and industry forecasting model, Studies in quantitative economics, Vol. 7 (University of Pennsylvania, Philadelphia).

Razin, A., 1993, The dynamic-optimizing approach to the current account: Theory and evidence, NBER Working Paper 4334.

Robinson, J., 1937, The foreign exchanges, in Essays in the theory of employment (Oxford University Press, Oxford).

Rose, A., 1991, The role of exchange rates in a popular model of international trade: Does the Marshall-Lerner condition hold?, Journal of International Economics 30, 301-316.

The Economist, 1993, A currency conundrum, October 2, p. 81.

Tsiang, S.C., 1961, The role of money in trade-balance stability: Synthesis of the elasticity and absorption approaches, American Economic Review 51, 912-936.

WEFA Group, 1982, Wharton long-term model structure and specification (The WEFA Group, Bala Cynwyd, Pennsylvania).

Yoshitomi, M., 1991, Surprises and lessons from Japanese external adjustment in 1985-1991, Ch. 3, in: C. F. Bergsten, ed., International adjustment and financing: The lessons from 1985 to 1991 (The Institute for International Economics, Washington) 123-144. 